\title{
Nanoparticles Toxicity and Their Routes of Exposures
}

\author{
Ahmet Aydın, Hande Sipahi and Mohammad Charehsaz \\ Additional information is available at the end of the chapter
}

http://dx.doi.org/10.5772/51230

\section{Introduction}

\subsection{Nanotechnology and nanomaterials}

Nanotechnology is a new area that presents small sized materials, structures, devices, and systems in last few decades. We hear about many materials and systems that contain nanomaterials nowadays. Most of the producers present their products as materials having excellent characteristics.

Due to their small size, nanotechnology based materials have unique characteristics such as magnetic, optical, thermal, mechanical, electrical, electron configuration density when compared with macromolecules. Nanomaterials are generally at the 1-100 nm scale and have a vast range of applications such as in medicine, electronics and energy production. Cosmetics, sunscreens, coatings, batteries, fuel additives, paints, pigments, tires and cement are the examples of consumer products that based on nanotechnology. Nanomaterials may also used for special medical purposes such as to produce novel drug delivery systems, to enhance the performance of medical devices, or to produce diagnostic-imaging materials [1].

\subsection{Nanomedicine}

The European Science Foundation [2] defines 'Nanomedicine' as the science and technology of diagnosing, treating and preventing disease and traumatic injury, of relieving pain, and of preserving and improving human health, using molecular tools and molecular knowledge of the human body. It is discussed under five main sub-disciplines as:

- Analytical tools

- Nanoimaging

- Nanomaterials and nanodevices

- Novel therapeutics and drug delivery systems

- Clinical, regulatory and toxicological issues. 
Although most nanotechnology deal with nanoparticles (NPs) sized below $100 \mathrm{~nm}$, in nanomedicine including drug delivery systems particle size is ranged from a few nanometers to $1000 \mathrm{~nm}$. Nanomedicines in practice are generally sized 5-250 nm [3]. In contrast to small sized nanomaterials, this relatively big dimension in drug delivery systems is sufficient to load the drugs onto the particles [4].

\subsection{Nanotechnology based novel drug delivery systems}

Nanosized drug delivery systems have already entered routine clinical use and Europe has been pioneering in this field [2]. Novel drug delivery systems are improving steadily in recent years. Main goals of these improvements are to achieve targetting of drug more specifically, to reduce toxicity of drug without the interfering of efficacy, to achieve biocompatibility, and to develop safe new medicines [4]. Nanotechnology is extensively used to produce the drug carriers having such kind of advantages, for example, carbon nanotubes (CNTs) are being used in targeted anticancer drug formulations and it has been shown to greatly improve the anticancer activity in animal models. Paclitaxel is another extensively studied anticancer molecule of which NP drug delivery formulation is prepared. This formulation enhanced cytotoxicity of paclitaxel on tumor cells in vitro and increased therapeutic efficacy in an animal model [5]

Nanomedicines produced with nanotechnology based engineered materials include proteins, polymers, dendrimers, micelles, liposomes, emulsions, NPs and nanocapsules [3].

\section{Nanotoxicology issue of novel drug delivery systems}

\subsection{Toxicological aspects of NPs}

Although nanoscale drug delivery systems are designed to reduce toxicity of drugs and to increase biocompatibility [6], there maight be some risks because of the unique characteristics of them. Due to these challenge, "nanotoxicology" term was adopted and defined as the science dealing with the effects of nanodevices and nanostructures in living organisms [7].

Nanoparticles have intrinsic toxicity profiles. Properties of nanoparticles that might increase the toxicity potential include i) particle size, ii) surface area and charge, iii) shape/structure, iv) solubility, and v) surface coatings [1]. Small size of NPs give rise to a high surface area per unit mass, and this surface area is often correlated with higher biological reactivity. In addition, formation of free radicals such as superoxide anion or hydroxyl radical may also be increased with high surface area. Accordingly oxidative stress may play an important role in NP toxicity especially for metal-based NPs. For example, inflammatory responses to NPs can be explained with these free radical formation [8].

Data on potential human and environmental exposure and dose-response relationship will be necessary to determine potential risks of nanomaterials following inhalation, oral or 
dermal routes of exposure. Significance of dose, dose rate, dose metric, and biokinetics are very useful parameters for the safety evaluation of newly engineered NPs.

One of the most common entry routes for NPs is inhalation. In vivo studies have demonstrated lung inflammation as a result of exposure to NPs [9]. Systemic distribution of NPs has been reported into the blood stream and lymphatic pathways [10].

Another important route for NP entry is the skin, from accidental exposure and use of cosmetics and other topical applications. Although the outer layer of the epidermis, the stratum corneum, protects against environmental insults, tittanium dioxide $\left(\mathrm{TiO}_{2}\right)$ has been shown to penetrate the stratum corneum and even hair follicles [11]. Penetration of nanosized $\mathrm{TiO}_{2}(5-20 \mathrm{~nm})$ into the skin and its interaction with the immune system has also been demonstrated [12].

Dey et al. [13] have demonstrated that nanosized alumina is internalized and significantly increases manganese superoxide dismutase (MnSOD) protein levels, indicating that the effect of alumina may occur, in part, via alteration of cellular redox status. It was also indicated that NP exposure can cause increased proliferation and anchorage-independent transformation in JB6 cells.

De Jong et al. [4] have summarized more striking toxicological effects of NPs in Table 1.

\subsection{Proposed mechanism of NP induced toxicity}

\subsubsection{Oxidative stress}

Through many researches, reactive oxygene species (ROS) production is increased at NP exposure. This phenomenon is called oxidative stress. Knaapen et al. [14] suggested three main factors which cause ROS release: (i) active redox cycling on the surface of NPs, particularly the metal-based NPs [15,16] (ii) oxidative groups functionalized on NPs; and (iii) particle-cell interactions, especially in the lungs where there is a rich pool of ROS producers like the inflammatory phagocytes, neutrophils and macrophages. Overproduction of ROS activates cytokines and upregulates interleukin (IL), kinases and tumor necrosis factor- $\alpha$ (TNF- $\alpha$ ) as an indicators of proinflammatory signaling processes as a counter reaction to oxidative stress [17].

Miura et al. reported that the expressions of ho- 1 and mt-2A, well-known oxidative stress related genes, were up-regulated by nano-silver treatment. These results indicated that apoptosis induction by silver nanoparticles (Ag NPs) may be created by ROS generation [18].

Potential role of oxidative stress as a mechanism of toxicity of AgNPs were evaluated by Hussain et al. [19]. In this study ROS generation following $6 \mathrm{~h}$ of exposure to $\operatorname{Ag}(15,100$ $\mathrm{nm})$ at $0,5,10,25$, and $50 \mathrm{~g} / \mathrm{mL}$ was investigated. The level of ROS in cells increased in a concentration dependent manner and was statistically increased from $10 \mathrm{~g} / \mathrm{mL}$ concentration. $\mathrm{Ag}(15,100 \mathrm{~nm})$ treatment at 25 and $50 \mathrm{~g} / \mathrm{mL}$ resulted in an approximately 10fold increase in ROS generation over control levels. 


\begin{tabular}{|c|c|}
\hline Description of finding, in vivo & Particle type \\
\hline NPs cause pulmonary inflammation in the rat. & All PSP \\
\hline $\begin{array}{l}\text { Later studies show that inflammation is mediated by } \\
\text { surface area dose. }\end{array}$ & SWCNT, MWCNT \\
\hline $\begin{array}{l}\text { NPs cause more lung tumors than fine particles in rat } \\
\text { chronic studies. Effect is surface area mediated. }\end{array}$ & PSP only. \\
\hline NPs cause progression of plague formation (ApoE-/-mice) & SWCNT, PM2.5 \\
\hline NPs affect immune response to common allergens. & Polystyrene, CB, DEP \\
\hline $\begin{array}{l}\text { NPs can have access to systemic circulation upon } \\
\text { inhalation and instillation. }\end{array}$ & $\begin{array}{l}\text { Specific NP, dependent on } \\
\text { surface coating. }\end{array}$ \\
\hline \multicolumn{2}{|l|}{ Description of finding, in vitro } \\
\hline $\begin{array}{l}\text { NPs cause oxidative stress in vivo and in vitro, by } \\
\text { inflammatory action and generation of surface radicals. } \\
\text { NPs inhibit macrophage phagocytosis, mobility and } \\
\text { killing. }\end{array}$ & PSP, NP general, CNT \\
\hline NPs cause platelet aggregation. & $\begin{array}{l}\text { PM, SWCNT, fullerenes, } \\
\text { latex-COOH surface }\end{array}$ \\
\hline $\begin{array}{l}\text { NPs exposure adversely affects cardiac function and } \\
\text { vascular homeostasis. }\end{array}$ & PM, SWCNT \\
\hline $\begin{array}{l}\text { NPs interfere with Ca-transport and cause increased } \\
\text { binding of pro-inflammatory transcription factor NF-kB. }\end{array}$ & $\begin{array}{l}\text { CB }(<100 \mathrm{~nm}), \quad \text { ROFA, } \\
\text { PM2.5 }\end{array}$ \\
\hline NPs can affect mitochondrial function. & Ambient NP \\
\hline NPs can translocate to the brain from the nose. & $\mathrm{MnO}_{2}, \mathrm{Au}$, carbon \\
\hline NPs do affect rolling in hepatic tissue. & $\mathrm{CB}$ \\
\hline
\end{tabular}

NP: nano particle, PSP: poorly soluble particles, DEP: diesel exhaust particles, SWCNT: single wall carbon nanotube, MWCNT: multi walled carbon nanotube, CB: carbon black, titanium dioxide:TiO2, PM: particulate matter, ROFA: residual oil fly ash, manganese dioxide: $\mathrm{MnO}_{2}$, PM2.5: particle mass fraction in ambient air with a mean diameter of 2.5 $\mu \mathrm{m}$.

Table 1. Toxicological effects of engineered and combustion NPs [4].

In another study intractions of AgNPs with human fibrosarcoma (HT-1080) and human skin/carcinoma (A431) cells was undertaken. When the cells was challenged with AgNPs $(6.25 \mu \mathrm{g} / \mathrm{mL})$, signs of oxidative stress such as decrease in oxyradical scavengers including reduced glutathione (GSH) and superoxide dismutase (SOD) as well as increase in lipid peroxidation were seen. Authors mentioned that observed SOD inactivation might be due to generation of peroxy radicals after AgNPs exposure [20].

Induction of oxidative stress and apoptosis by AgNPs in the liver of adult zebrafish was studied by Choi et.al. The results indicated that the levels of malondialdehyde (MDA), a product of cellular lipid peroxidation, and total GSH were increased in the tissues after treatment with AgNPs. The mRNA levels of the oxyradical scavenging enzymes catalase (CAT) and glutathione peroxidase 1a (GPx 1a) were reduced in the tissues. Authors 
concluded that the increased level of hepatic MDA indicates that AgNPs induced oxyradicals in the liver. In addition, the induction of an endogenous antioxidant, GSH, suggests that the liver tissues respond defensively to the increased level of oxyradicals. Also the reduction of the levels of CAT and GPx may thus result in the accumulation of hydrogen peroxide $\left(\mathrm{H}_{2} \mathrm{O}_{2}\right)$ and other oxyradicals [21]. The elevated oxidative stress can damage lipids, carbohydrates, proteins and DNA.

Some investigations reported that $\mathrm{TiO}_{2}$ increased intracellular ROS generation and MDA concentration in a dose-dependent manner $[22,23]$. The mechanism by which $\mathrm{TiO}_{2} \mathrm{NPs}$ can generate free radicals is through decreasing the activities of antioxidant enzymes such as SOD, CAT, GPx and glutathione reductase (GR) or intracellular levels of antioxidants such as GSH and ascorbic acid [24-27].

Ramkumar et al. reported that the ratio of GSH/GSSG, a good indicator of the levels of cellular oxidative stress, was found to be decreased dose dependently in the $\mathrm{TiO}_{2}$ treated cells [22] and thus preserving the GSH-mediated antioxidant defense that is critical for cell survival. It is possible that the loss of GSH may compromise cellular antioxidant defenses and led to the accumulation of ROS and free radicals that are generated in response to exposure to NPs or as by products of normal cellular function.

In line with these findings, Sun et al. investigated the generating of superoxide $\left(\mathrm{O}_{2}{ }^{-}\right)$and $\mathrm{H}_{2} \mathrm{O}_{2}$ after long-term exposure to $\mathrm{TiO}_{2} \mathrm{NPs}$ in mice [28]. Results showed that the production rates of $\mathrm{O}_{2}-$ and $\mathrm{H}_{2} \mathrm{O}_{2}$ in $\mathrm{TiO}_{2}$ treated group were significantly higher than those of control. It is also reported that exposure to $\mathrm{TiO}_{2} \mathrm{NPs}$ elicits lipid peroxidation levels in the mouse lung. Since ROS act as second messengers in intracellular signaling cascades [29], the increase in ROS by $\mathrm{TiO}_{2}$ NPs exposure may play an important role in the modulation of gene expression and resultant inflammation or apoptosis.

Li et al. investigated the oxidative stress associated with gold NPs (Au NPs) in human lung fibroblast cells [30]. It was observed that the Au NPs treated cells generated significantly more lipid hydroperoxides, a positive indicator of lipid peroxidation, than the control cells. In addition, MDA modified protein adducts were evaluated by western blotting as a further verification of the presence of lipid peroxidation. MDA reacts readily with protein or DNA forming adducts which are considered to be highly genotoxic. The results obtained from this study clearly showed that the amount of proteins alkylated by MDA was significantly more in the AuNPs treated samples than that in control samples.

Jia et al. [31] reported that Au NPs can catalyze nitric oxide (NO), a reactive nitrogen species, generation from endogenous S-nitroso adducts with thiol group (RSNOs) whenever they come into contact with fresh blood serum. RSNOs, such as S-nitrosoalbumin, Snitrosocystein and S-nitrosoglutathione, is a more abundant and stable form of NO in blood since NO has a relative short lifetime in blood because of its reactivity with various blood components. One notable reaction of RSNO dissociation to yield NO is catalyzed by metal ions including $\mathrm{Au}$ NPs. $\mathrm{NO}$ reacts rapidly with $\mathrm{O}_{2}{ }^{-}$. and produces a harmful peroxynitrite (ONOO-) species. ONOO- can disrupt lipids, DNA, and proteins. 
Another study, conducted by Tedesco et al. [32], investigated the oxidative stress and toxicity of AuNPs in Mytilus edulis (blue mussel). In this study M. edulis was exposed to 750 ppb AuNP (average diameter $5.3 \pm 1 \mathrm{~nm}$ ) for 24 hours to investigate in vivo biological effects of nanoparticles. Traditional biomarkers and an affinity procedure selective for thiolcontaining proteins were used to study toxic and oxidative stress responses. Protein thiols can play a role in antioxidant defense and absorption of ROS. M. edulis that was exposed to $\mathrm{Au}$ NP were displayed a decreased amount of thiol containing proteins in comparison both to controls and those treated with cadmium chloride $\left(\mathrm{CdCl}_{2}\right)$ (a well known pro-oxidant). This result was consistent with direct oxidation of thiols by ROS induced by AuNP. Also this was supported by more traditional independent measures of biological and oxidative stress such as lysosomal membrane stability and lipid peroxidation. Lysosomal membrane stability measured as neutral red retention time showed a decrease for both $\mathrm{Au} \mathrm{NP}$ and $\mathrm{CdCl}_{2}$ treatments confirming significant biological stress. The effect was stronger in the case of $\mathrm{Au} \mathrm{NP}$ than $\mathrm{CdCl}_{2}$. This study also showed that $\mathrm{Au}$ NP caused significant lipid peroxidation in digestive gland of M. edulis. This study suggested that M. edulis is a suitable model animal for environmental toxicology studies of nanoparticles.

Due to the interesting magnetic and electrical properties with good chemical and thermal stabilities, spinal ferrite nanoparticles such as nickel ferrite are used in bioapplications including magnetic resonance imaging, drug delivery and hyperthermia [33-37]. However, little is known about the toxicity of spinal ferrite nanoparticles at the cellular and molecular levels. Ahamed et al. investigated oxidative stress mediated apoptosis induced by nickel ferrite nanoparticles in human lung epithelial (A549) cells [38]. In this study the potential of nickel ferrite nanoparticles to induce oxidative stress was assessed by measuring the ROS and GSH levels in A549 cells. Results showed that the nickel ferrite nanoparticles significantly induced the production of ROS and reduced the level of intracellular GSH in these cells. Further, co-treatment with the antioxidant L-ascorbic acid migrated the ROS generation and GSH depletion due to nickel ferrite nanoparticles exposure. These results indicated that nickel ferrite nanoparticles induced oxidative stress in A549 cells by induction of ROS and depletion of GSH.

\subsubsection{Phagocytosis of NPs and inflammation}

In respiratory tract, mucociliary clearance removes particulate matter (PM) in $<6 \mu \mathrm{m}$ diameter. Alveolar macrophages engulf and process particles that are not cleared by mucociliary action and coughing. Upon phagocytosis macrophages are activated to release substantial amounts of oxygen radicals, proteolytic enzymes, proinflammatory mediators and growth-regulating proteins. These mediators may lead to both acute and chronic lung inflammation [17].

As other NPs, the toxicity of Ag NPs appears to be driven by their oxidative and inflammatory nature, which then drives genotoxic and cytotoxic outcomes [39].

Carlson et al. [40], investigated the size-dependent cellular interactions of Ag NPs in rat alveolar macrophages (NR8383) cell culture. In this study cells were exposed to 0, 5, 10 and 
$25 \mu \mathrm{g} / \mathrm{mL}$ Ag NPs (15 nm, $30 \mathrm{~nm}$ and $55 \mathrm{~nm}$ ) for 24 hours and levels of characteristic markers of macrophage activation such as TNF- $\alpha$, macrophage inhibitory protein-2 (Mip-2), IL-1 $\beta$ and IL- 6 . The results demonstrated significant levels of TNF- $\alpha$, Mip-2, IL-1 $\beta$ at 5, 10 and $25 \mu \mathrm{g} / \mathrm{mL}$ for all sizes of Ag NPs comparing to the control group. However, there was no detectable level of IL-6 upon exposure to Ag NPs. Also the cytotoxicity of Ag NPs were evaluated by MTT metabolic activity assay (3-(4,5-Dimethylthiazol-2-yl)-2,5diphenyltetrazolium bromide) and membrane integrity (lactic dehydrogenase (LDH)) assays. The results of the MTT viability assay showed a significant decrease in mitochondrial function of alveolar macrophages exposed to Ag NPs at $15 \mathrm{~nm}, 30 \mathrm{~nm}$, or 55 $\mathrm{nm}$ for $24 \mathrm{~h}$ at concentrations ranging from 10 to $75 \mu \mathrm{g} / \mathrm{mL}$. It was noted that compared to the smaller nanoparticles (15 and $30 \mathrm{~nm}$ ), $55 \mathrm{~nm}$ did not exhibit significant toxicity until 50$75 \mu \mathrm{g} / \mathrm{mL}$. Similarly to the MTT data, the results of LDH assay showed a dose-dependent decrease in cell viability compared to control cells after $24 \mathrm{~h}$ of exposure to Ag NPs. Ag NPs at 15 and $30 \mathrm{~nm}$ exhibited significant cytotoxicity at $10-75 \mu \mathrm{g} / \mathrm{mL}$, whereas $55 \mathrm{~nm}$ required a concentration of $75 \mu \mathrm{g} / \mathrm{mL}$ to markedly decrease cell viability according to LDH assay results.

In another study, Park et al. [41] measured secreted NO levels, as a second messenger in inflammatory signaling, to investigate the correlation of nitrosative-oxidative stress and cytotoxicity induced by Ag NPs. The mouse peritoneal macrophage (RAW264.7) cell line were exposed to $0.2,0.4,0.8$ and $1.6 \mu \mathrm{g} / \mathrm{mL} \mathrm{Ag} \mathrm{NPs}(68.9 \mathrm{~nm})$ for 24, 48, 72 and 96 hours. Results showed that NO secretion was increased 2-fold over the control group by Ag NPs at $1.6 \mu \mathrm{g} / \mathrm{mL}$. Also TNF- $\alpha$ level was increased almost 2.8-fold and GSH level was decreased by the same concentration comparing to control group. Ultimately, the phagocytosis of Ag NPs stimulated inflammatory signaling through the ROS generation in macrophages followed by the induced secretion of TNF- $\alpha$. The increase of TNF- $\alpha$ can cause damage of cell membrane and apoptosis. Authors concluded that ionization of Ag NPs can be a major factor for all these results in cells.

Park et al. [42] also conducted a 28-day oral administration study in mice to investigate toxicity and inflammatory responses of $0.25,0.5$ and $1 \mathrm{mg} / \mathrm{kg} \mathrm{Ag} \mathrm{NPs} \mathrm{(42} \mathrm{nm).} \mathrm{Evaluation} \mathrm{of}$ inflammatory responses by repeated administration of AgNPs were conducted by measurement of pro-inflammatory cytokines (IL-1, TNF- $\alpha$ and IL-6), Th1-type cytokines (IL12 and interferon-gamma), Th2-type cytokines (IL-4, IL-5, IL-10) and transforming growth factor beta (TGF- $\beta$ ) concentrations in serum. The results showed that IL-1 was significantly increased by Ag NPs. TNF- $\alpha$ and IL-6 were increased almost 2.8-fold and 9.5-fold of the control group, respectively. Also both Th1-type cytokines and Th2-type cytokines showed a significant increase. TGF- $\beta$ which is known as tissue damage-related cytokines, was also increased in a dose-dependent manner.

Also some studies reported that exposure to $\mathrm{TiO}_{2} \mathrm{NPs}$ results in pulmonary inflammation, pulmonary edema, macrophages accumulation and pneumonocyte apoptosis [28, 43-45].

Jacobsen et al. [46] studied inflammatory potential after intratracheal instillation of 5 different types of nanoparticles $(\mathrm{CB}$, gold clusters, fullerense $\mathrm{C} 60$, SWCNT and quantum 
dots) for pulmonary effects in apolipoprotein E knockout mice. Results indicated significant increases in mRNA levels of Mip-2, IL-6 and macrophages/monocyte chemoattractant protein-1 (Mcp-1) in lung tissue following $3 \mathrm{~h}$ and $24 \mathrm{~h}$ instillation of SWCNT, CB and quantum dots. Also gold and fullerense C60 were found less potent at the three end points when compared to others.

Gosens et al. [47] administered a single dose of $1.6 \mathrm{mg} / \mathrm{kg}$ bw of single $(50 \mathrm{~nm})$ and agglomerated $(250 \mathrm{~nm})$ gold particles in the rat lung by intratracheal instillation. Findings showed that both single and agglomerated particles were taken up by macrophages. Both particles increased inflammatory cells and pro-inflammatory cytokine production. The effects were the least for $50 \mathrm{~nm}$ Au NPs.

In line with these findings, Cho et al. [48] reported that Au NPs sized at $13 \mathrm{~nm}$ induced acute inflammation and apoptosis in the liver of $\mathrm{BALB} / \mathrm{c}$ mice after intravenous administration.

Downs et al. [49] measured TNF- $\alpha$ and IL-6 in plasma samples of the rats intraperitoneally treated with silica NPs (15 nm and $55 \mathrm{~nm}$ ) and crystalline silica (quartz) particles (400 nm). The largest increases in the plasma levels of cytokines were found in the animals exposed to $125 \mathrm{mg} / \mathrm{kg}$ (the highest dose) of both the $15 \mathrm{~nm}$ and $55 \mathrm{~nm}$ silica NPs and the quartz particles. A remarkable increase in the levels of both TNF- $\alpha$ and IL- 6 was found in the rats treated with the $15 \mathrm{~nm}$ silica NPs at $50 \mathrm{mg} / \mathrm{kg}$ dose (middle dose), but not at the $25 \mathrm{mg} / \mathrm{kg}$ dose (low dose). Treatment with the $55 \mathrm{~nm}$ silica NPs resulted in a 1.5-fold and a 2.3-fold increase in TNF- $\alpha$ and IL-6 levels at $125 \mathrm{mg} / \mathrm{kg}$, respectively, but no change was observed in IL-6 levels at the $25 \mathrm{mg} / \mathrm{kg}$ doses. Quartz particles showed a 2.3-fold and 2.1-fold induction of TNF- $\alpha$ and IL- 6 production, respectively, at the $100 \mathrm{mg} / \mathrm{kg}$ dose.

\subsubsection{Genotoxicity}

NanoGenotoxicology is yet another new term that was coined to represent the growing trend of research into NP-induced genotoxicity and carcinogenesis [17]. Although there is still no exact correlation between NP-induced genotoxicity and lung cancer from epidemiological studies and in vivo rodent experiments, it is pointed out in literature that long-term inflammation and oxidative stress present in tissue can eventually induces DNA damage in cells and tissues. Continuous ROS production in the cell can cause gene mutations/deletions leading to mutagenesis, carcinogenicity, and subsequently development of tumors and cancer. Particularly the metal based NPs like Ag NPs [19], Au NPs [30] and $\mathrm{TiO}_{2}$ NPs [22] are important for that kind of ROS production and genetic damage. As a result of DNA damage induced by NPs, single-strand DNA breaks, doublestrand breaks, DNA deletions and genomic instability in the form of increase in 8-hydroxy2-deoxyguanosine levels are formed [50]. According to Mroz et al.[ 51] long-term exposure of cells to NPs displayed genome instability under comet assay analysis, altered cell cycle kinetics in flow cytometry and induced protein expression of p53, having a critical role in responding to various stresses that cause DNA damage, and DNA repair-related proteins. 
Li et al. [52] studied the genotoxicity of $5 \mathrm{~nm}$ Ag NPs using two standard genotoxicity assays, the Salmonella reverse mutation assay (Ames test) and the in vitro micronucleus assay. Results demonstrate that $5 \mathrm{~nm}$ AgNPs did not induce mutations in five different $S$. typhimurium strains (TA102, TA100, TA1537, TA98 and TA1535). However, Ag NPs displayed concentration-dependent genotoxicity in the human lymphoblast TK6 cell micronucleus assay. Ag NPs produced statistically significant increases in micronucleus frequency in the assay. The data suggest that the in vitro micronucleus assay may be more appropriate than the Ames test for evaluating the genotoxicity of the AgNPs.

Ahamed et al. [53] investigated the ability of uncoated or polysaccharide-coated Ag NPs (25 $\mathrm{nm}$ ) to elicit DNA damage within two types of mammalian cells; mouse embryonic stem cells (mES) and mouse embryonic fibroblasts (MEF). mES and MEF cell lines were exposed to AgNPs at a concentration of $50 \mu \mathrm{g} / \mathrm{mL}$ for a duration of up to 72 hours. Results showed that the proteins p53 and Rad51, responsible for DNA double-strand repair, were upregulated in two types of mammalian cells. Also in this study DNA double strand breakage induced by AgNPs was confirmed by both immunofluorescent and immunoblot analysis of phospho-H2AX which is ordinarily induced by DNA double-strand breakage. Results indicated that phosphorylation of the histone H2AX were induced by AgNPs. Also this study suggested that the polysaccharide coated AgNPs are more individually distributed and exhibited more severe damage than uncoated AgNPs. This finding may be related with the agglomeration of the uncoated particles and restriction of their cellular distribution.

In an in vivo study, Kim et al. [54] conducted a 90-day whole-body inhalation study (6 hours day $/ 5$ days a week) to $\operatorname{AgNPs}(18 \mathrm{~nm})$ in rats at low $\left(0.7 \times 106\right.$ particles $\left./ \mathrm{cm}^{3}\right)$, middle $(1.4 \times$ 106 particles $\left./ \mathrm{cm}^{3}\right)$ and high $\left(2.9 \times 106\right.$ particles $\left./ \mathrm{cm}^{3}\right)$ doses. After sacrificing of rats, micronucleus induction was measured in the bone marrow according to the test guideline 474 issued by OECD. Authors found out that AgNPs did not affect either the frequency of micronucleated polychromatic erythrocytes (PCE) as an indicator of DNA damage or the PCE / (PCE+NCE) ratio as an indicator of toxicity to bone marrow cells (NCE: normochromatic erythrocytes) in male and female rats. The authors concluded that exposure to AgNPs by inhalation for 90 days does not induce genetic toxicity in male and female rat bone marrow in vivo.

Also the same authors conducted an in vivo micronucleus assay after 28-day oral administration of Ag NPs. The results were similar to those of inhalation study [55].

A number of studies have shown that $\mathrm{TiO}_{2} \mathrm{NPs}$ exhibited genotoxicity in cultured cell lines [56-58]. Kang et al. [59], studied the genotoxic effects of $\mathrm{TiO}_{2} \mathrm{NPs}(20-100 \mu \mathrm{g} / \mathrm{ml})$ in human peripheral blood lymphocyte cells using alkaline single cell gel electrophoresis (Comet) and cytokinesis block micronucleus (CBMN) assays. The CBMN assay results showed that the micronuclei frequency increased in a dose-dependent manner. Also cells had a significant olive tail moment which indicates unrepaired DNA strand breaks in comet assay.

Similarly, Wang et al. [60] investigated the toxicity of ultrafine $\mathrm{TiO}_{2}$ particles in cultured human B-cell lymphoblastoid cell line (WIL2-NS). Significant increases in the micronuclei 
frequency were detected by the CBMN assay in a dose-dependent manner. In the comet assay, 3-fold increase in \%Tail DNA were found when the cells were treated with ultrafine $\mathrm{TiO}_{2}$ at a dose of $65 \mu \mathrm{g} / \mathrm{mL}$ for 24 hours exposure. In the olive tail moment a 5-fold elevation was found at the same dose and exposure duration. Also a linear relationship was determined between the mutation frequency and concentration in the clonal selection assay for the hypoxanthine-guanine phosphoribosyl transferase (HPRT) gene.

Toyooka et al. [61] examined the genotoxicity of $\mathrm{TiO}_{2} \mathrm{NPs}(5 \mathrm{~nm})$ and microparticles $(<5000$ $\mathrm{nm}$ ) in the lung adenocarcinoma epithelial cell line (A549) based on the phosphorylation of histone $\mathrm{H} 2 \mathrm{AX}(\gamma-\mathrm{H} 2 \mathrm{AX})$ as a new sensitive biomarker for DNA damage. Results showed that $\mathrm{TiO}_{2}$ particles have the ability to generate $\gamma-\mathrm{H} 2 \mathrm{AX}$ and this was more remarkable with nanoparticles than microparticles.

Contrary to above studies, a number of investigations showed that $\mathrm{TiO}_{2} \mathrm{NPs}_{\mathrm{s}}$ didn't induce DNA damage and mutation using the Ames test, micronucleus assay, comet assay, and etc. [62-68].

$\mathrm{Au}$ NPs are also recognized in their ability to contribute in genotoxicity. Schulz et al. [69] investigated two genotoxic endpoints, alkaline comet assay in lung tissue and micronucleation in PCE of the bone marrow, 72 hours after a single instillation of $18 \mu \mathrm{g}$ uncoated Au NPs in different sizes (2, 20 and $200 \mathrm{~nm}$ ) into the trachea of male adult Wistar rats. Results indicated that AuNPs in the different sizes were non-genotoxic and showed no systemic and local adverse effects at the given dose.

Also the genotoxicity of zinc oxide nanoparticles ( $\mathrm{ZnO} \mathrm{NPs}$ ), widely used in cosmetics and sunscreens, was evaluated in some studies. Sharma et al. [70] investigated the genotoxicity of these nanoparticles in primary human epidermal karatinocytes using comet assay. Results showed a significant induction in DNA damage in cells exposed to 8 and $14 \mu \mathrm{g} / \mathrm{mL}$ $\mathrm{ZnO}$ NPs for 6 hours comparing to control group. Finding demonstrated that ZnO NPs are assimilated by the human epidermal karatinocytes and induce cytotoxic and genotoxic responses.

Also in another study Sharma et al. [71] highlighted the in vitro genotoxicity of ZnO NPs in human liver cells (HepG2). Similarly significant increase in DNA damage was observed in cells in the comet assay.

Fen Song et al. [50] analyzed the induction of reticulocyte micronuclei and oxidative DNA damage in ICR female mice after intraperitoneal injection of metal oxides $\left(\mathrm{CuO}, \mathrm{Fe}_{2} \mathrm{O}_{3}\right.$, $\left.\mathrm{Fe}_{3} \mathrm{O}_{4}, \mathrm{TiO}_{2}\right)$ and $\mathrm{Ag} \mathrm{NPs}$ at various doses $(0,1,3 \mathrm{mg} / \mathrm{mouse})$. The results of the micronucleus assay demonstrated significant increases in micronucleated reticulocyte formation after the intraperitoneal administration of $\mathrm{CuO}, \mathrm{Fe}_{2} \mathrm{O}_{3}, \mathrm{Fe}_{3} \mathrm{O}_{4}, \mathrm{TiO}_{2}$ and $\mathrm{Ag} \mathrm{NPs}$. Also the levels of 8-hydroxydeoxyguanosine $(8-\mathrm{OH}-\mathrm{dG})$ which is one of the most well studied biomarkers to measure the oxidative damage in DNA was evaluated in liver and bone marrow DNA and urine after the administration of metal oxide and Ag NPs. The urinary level of 8-OH-dG was significantly increased by the $\mathrm{CuO}$ at each time point of the urine analysis. Although the increases in the urinary levels of $8-\mathrm{OH}-\mathrm{dG}$ for the other 
nanoparticle treatments were not significant, all of the other metal compounds showed higher levels of urinary 8-OH-dG than the control. The 8-OH-dG levels in the bone marrow immediately increased after the injection of $\mathrm{CuO}$, and continued to increase up to $24 \mathrm{~h}$ after administration. Also the 8-OH-dG levels in the liver DNA of the mice treated with $3 \mathrm{mg} \mathrm{CuO}$ were significantly higher than those in the non-treated control. The increase of 8-OH-dG levels in the liver DNA continued for $72 \mathrm{~h}$ after the administration of 1 and $3 \mathrm{mg}$ doses of $\mathrm{CuO}$. The other nanoparticles did not cause an increase in the liver 8$\mathrm{OH}-\mathrm{dG}$ level at $24 \mathrm{~h}$ after administration. Authors concluded that metal oxide nanoparticles can cause genotoxic effects in vivo. Among them, the $\mathrm{CuO}$ NPs were the most potent, iron oxide NPs also showed relatively high toxicity and $\mathrm{TiO}_{2}$ and $\mathrm{Ag} \mathrm{NPs}$ showed low toxicity.

\section{Toxicity assessment of novel drug delivery systems}

Lack of full toxicological knowledge about nanomaterials including novel drug delivery systems lead to the misperception regarding all nanomaterials pose a significant health risk. Under such realistic conditions, many engineered NPs are unlikely to induce adverse effects although effects of chronic and low level exposures are still largely unknown. Owing to extensive toxicological studies it will be possible to do exact risk assessment related with NPs.

Identification of potential health risks is a prerequisite for assessing the safety of the new products that are being developed. That is why, nanotoxicology area is gaining increasing importance with the growth of nanotechnological applications. Safety evaluation of nanomaterials through toxicological research will also provide information about their undesirable properties. These information will also help to avoid their possible adverse effects [7].

Toxicity studies on nanoparticles are generally conducted at very high doses. With high doses, any NP can be identified as toxic in living systems. A more realistic approach will be to discriminate high doses tested and tests under real exposure conditions. Therefore non in vivo assays for the purpose of extrapolating the responses to in vivo results may reduce and avoid a lot of laboratory animals. Beside occupational exposure to NP where they are produced and intentional use of consumer goods containing NP should be evaluated. With respect to nanomedicine, in vivo tests will always be mandatory for nanotechnology-based therapeutics and diagnostics [72].

As mentioned by Oberdorster [72], a tiered testing system to assess NP toxicity was suggested by a working group of the International Life Sciences Institute (ILSI) [73]. Table 2 lists the tiered testing strategy including physico-chemical characterization prior to and during testing in cell-free, cellular and in vivo assays. Studies designed to determine whether in vitro assays are predictive for in vivo effects have come to opposite conclusions. 


\section{Dose concepts in NP toxicology}

Classical mass dose trend applied in conventional toxicological research may not be sufficient in nanotoxicological testing due to the extensively large surface area compairing with large particles. Oberdorster [74] studied the toxicity of ultrafine and fine $\mathrm{TiO}_{2}$ measuring polymorphonuclear neutrophils in lung lavage fluid as an index of inflammation and they found ultrafine $\mathrm{TiO}_{2}$ as more toxic than fine $\mathrm{TiO}_{2}$ considering mass unit dose. When considered surface area, the toxicity was equivalent.

- $\quad$ Physico-chemical characterization

- Cell-free assays (solubility; ROS generating potential; chemreactivity; agglomeration/aggregation; zeta potential; other)

- Cellular assays [primary cells; cell-lines; (primary and secondary organs); co-cultures]

- In vivo assays [generally rodents; diverse methodologies (resp. tract; skin; GI-tract)]

- Question

Can any of the in vitro tests be used to predict in vivo toxicity?

Table 2. Tiered testing system to assess NP toxicity (ILSI Report) [73]

In vivo and in vitro test correlation is critical point in safety evaluations. The dose unit considered in the evaluations may affect the correlations between in vitro and in vivo tests directly. Say et al. studied fine and nanoparticle toxicity assessing in alveolar macrophages and a pulmonary epithelial cell line and then comparing them with the in vivo pulmonary inflammation induced by the same particles in rats [75]. They could not find a significant in vitro - in vivo correlation and suggested more sophisticated in vitro cell culture systems to gauge the relative toxicity of nanoparticles in vivo. When these results were analyzed according to the new approach suggested by Rushton et al. [76] who used NP surface area as a dose unit, the in vitro and in vivo results of Say et al. were correlated significantly.

\section{Conclusion}

As said by Oberdorster [72], nanotechnology, nanomedicine and nanotoxicology are closely related disciplines aimed at the improvement of human life. As a result of introducing of nanotechnology based nanomaterial into nanomedicine, novel and superior diagnostic, therapeutic and preventive systems have emerged. The safety assessment of these new materials is mandatory to recognize risks and avoid potential hazards. This assessment also provide useful information to avoid disinformation about the toxicity potential of nanosized systems. At this point nanotoxicology will have a crucial role. Material scientists, physicians, pharmacists and toxicologists should be included in nanotechnological developments as a team aproach.

As a result, it is important that safety assessments and health risks of novel drug delivery systems including nanomaterials should be made with the available and produced data. Nanomaterials should be evaluated on case-by-case basis in place of general evaluations for NPs. 


\section{Author details}

Ahmet Aydın*, Hande Sipahi and Mohammad Charehsaz

Yeditepe University, Faculty of Pharmacy, Department of Toxicology, Istanbul, Turkey

\section{References}

[1] Society of Toxicology. SOT: Developing Safe Products Using Nanotechnology. http://www.toxicology.org (accessed 20 April 2012).

[2] European Science Foundation. ESF: Nanomedicine. http://www.esf.org (accessed 20 April 2012).

[3] ] Garnett MC and Kallinteri P. Nanomedicines and Nanotoxicology: Some Physiological Principles. Occupational Medicine 2006;56:307-311.

[4] De Jong WH and Borm PJA. Drug Delivery and Nanopartciles. Applications and Hazards. International Journal of Nanomedicine 2008;3(2):133-149.

[5] Win KY, and Feng SS. In Vitro and In Vivo Studies on Vitamin E TPGS-emulsified Poly(D,L-lactic-co-glycolic acid) Nanoparticles for Paclitaxel Formulation. Biomaterials 2006; 27:2285-91.

[6] Rangasamy M and Parthiban KG. Recent Advances in Novel Drug Delivery Systems. International Journal of Research in Ayurveda \& Pharmacy 2012;1(2):316-326.

[7] Oberdörster G, Oberdörster E, and Oberdörster J. Nanotoxicology: An Emerging Discipline Evolving from Studies of Ultrafine Particles. Environmental Health Perspectives 2005; 113:823-839.

[8] Donaldson K, Aitken R, Tran L, Stone V, Duffin R, Forrest G, and Alexander A. Carbon Nanotubes: A Review of Their Properties in Relation to Pulmonary Toxicology and Workplace Safety. Toxicological Sciences 2006;92(1):5-22

[9] Dailey LA, Jekel N, Fink L, Gessler T, Schmehl T, Wittmar M, Kissel T, Seeger W. Investigation of The Proinflammatory Potential of Biodegradable Nanoparticle Drug Delivery Systems in The Lung. Toxicology and Applied Pharmacology 2006;215:100108.

[10] Medina C, Santos-Martinez MJ, Radomski A, Corrigan OI and Radomski MW. Nanoparticles: pharmacological and toxicological significance. British Journal of Pharmacology 2007;150:552-558.

[11] Lademann J, Weigmann H, Rickmeyer C, Barthelmes H, Schaefer H, Mueller G, Sterry W. Penetration of Titanium Dioxide Microparticles in a Sunscreen Formulation Into The Horny Layer and The Follicular Orifice. Skin Pharmacology and Applied Skin Physiology 1999;12(5):247-56.

[12] Kreilgaard M. Influence of Microemulsions on Cutaneous Drug Delivery. Advanced Drug Delivery Reviews 2002;54 Suppl.1 S77-S98.

[13] Dey S, Bakthavatchalu V, Tseng MT, Wu P, Florence RL, Grulke EA, Yokel RA, Dhar SK, Yang H, Chen Y, and Clair DK. Interactions Between SIRT1 and AP-1 Reveal a

\footnotetext{
${ }^{*}$ Corresponding Author
} 
Mechanistic Insight Into the Growth Promoting Properties of Alumina (Al2O3) Nanoparticles in Mouse Skin Eepithelial Cells. Carcinogenesis 2008;29(10):1920-1929.

[14] Knaapen AM, Borm PJA, Albrecht C, Schins RPF. Inhaled Particles and Lung Cancer. Part A: Mechanisms. International Journal of Cancer 2004;109:799-809.

[15] Fahmy B, Cormier SA. Copper Oxide Nanoparticles Induce Oxidative Stress and Cytotoxicity in Airway Epithelial Cells. Toxicology In Vitro 2009;23:1365-71.

[16] Lopez N, Norskov JK. Catalytic CO Oxidation by a Gold Nanoparticle: A Density Functional Study. Journal of American Chemical Society 2002;124:11262-3.

[17] ] Jia'en Li J, Muralikrishnan S, Ng CT, Yung LYL and Bay BH. Nanoparticle-Induced Pulmonary Toxicity. Experimental Biology and Medicine 2010;235:1025-1033.

[18] Miura N, Shinohara Y. Cytotoxic Effect and Apoptosis Induction by Silver Nanoparticles in Hela Cells. Biochemical and Biophysical Research Communinations 2009;390:733-737.

[19] Hussain SM, Hess KL, Gearhart JM, Geiss KT, Schlager JJ. In Vitro Toxicity of Nanoparticles in BRL 3A Rat Liver Cells. Toxicology in Vitro 2005;19:975-983.

[20] Arora S, Jain J, Rajwade JM, Paknikar KM. Cellular Responses Induced by Silver Nanoparticles: in Vitro Studies. Toxicology Letters 2008;179:93-100.

[21] Choi JE, Kim S, Ahn JH, Youn P, Kang JS, Park K, Yi J, Ryu DY. Induction of Oxidative Stress and Apoptosis by Silver Nanoparticles in the Liver of Adult Zebrafish. Aquatic Toxicology 2010;100:151-159.

[22] Ramkumar KM, Manjula C, Gnanakumar G, Kanjwal MA, Sekar TV, Paulmurugan R, Rajaguru P. Oxidative Stress-Mediated Cytotoxicity and Apoptosis Induction by TiO2 Nanofibers in Hela Cells. European Journal of Pharmaceutics and Biopharmaceutics 2012;81:324-333.

[23] Gurr JR, Wang AS, Chen CH, Jan KY. Ultrafine Titanium Dioxide Particles in the Absence of Photoactivation Can Induce Oxidative Damage to Human Bronchial Epithelial Cells. Toxicology 2005;213:66-73.

[24] Hu RP, Zheng L, Zhang T, Cui YL, Gao GD, Cheng Z, Chen J, Tang M, Hong FS. Molecular Mechanism of Hippocampal Apoptosis of Mice Following Exposure to Titanium Dioxide Nanoparticles. Journal of Hazardous Materials 2011;191:32-40.

[25] Ma LL, Liu J, Li N, Wang J, Duan YM, Yan JY, Liu HT, Wang H, Hong FS. Oxidative Stress in the Brain of Mice Caused by Translocated Nanoparticulate $\mathrm{TiO}_{2}$ Delivered to the Abdominal Cavity. Biomaterials 2010;31:99-105.

[26] Liu HT, Ma LL, Liu J, Zhao JF, Yan JY, Hong FS. Toxicity of Nanoanatase $\mathrm{TiO}_{2}$ to Mice: Liver Injury, Oxidative Stress. Toxicological and Environmental Chemistry 2010;92:175186.

[27] Long TC, Tajuba J, Sama P, Saleh N, Swartz C, Parker J, Hester S, Lowry GV, Veronesi B. Nanosized Titanium Dioxide Stimulates Reactive Oxygen Species in Brain Microglia and Damages Neurons in Vitro. Environmental Health Perspectives 2007;115:1631-1637.

[28] Sun Q, Tan D, Zhou Q, Liu X, Cheng Z, Liu G, Zhu M, Sang X, Gui S, Cheng J, Hu R, Tang M, Hong F. Oxidative Damage of Lung and its Protective Mechanisim in Mice Caused by Long-Term Exposure to Titanium Dioxide Nanoparticles. Journal of Biomedical Materials Research Part A 2012; DOI: 10.1002/jbm.a.34190. 
[29] Valko M, Rhodes CJ, Moncol J, Izakovic M, Mazur M. Free Radicals, Metals and Antioxidants in Oxidative Stress-Induced Cancer. Chemico-Biological Interactions 2006;160:1-40.

[30] Li JJ, Hartono D, Ong CN, Bay BH, Yung LYL. Autophagy and Oxidative Stress Associated with Gold Nanoparticles. Biomaterials 2010;31:5996-6003.

[31] Jia HY, Liu Y, Zhang XJ, Han L, Du LB, Tian Q, Xu YC. Potential Oxidative Stress of Gold Nanoparticles by Induced-No Raleasing in Serum. Journal of the American Chemical Society 2009;131:40-41.

[32] Tedesco S, Doyle H, Blasco J, Redmond G, Sheehan D. Oxidative Stress and Toxicity of Gold Nanoparticles in Mytilus edulis. Aquatic Toxicology 2010;100:178-186.

[33] Willard MA, Kurihara LK, Carpenter EE, Calvin S, Harris VG. Chemically Prepared Magnetic Nanoparticles. International Materials Reviews 2004;49:125-170.

[34] Lee JH, Huh YM, Jun YW, Seo JW, Jang JT, Song HT, Kim S, Cho EJ, Yoon HG, Suh JS, Cheon J. Artificially Engineered Magnetic Nanoparticles for Ultra-Sensitive Molecular Imaging. Nature Medicine 2007;13:95-99.

[35] Rana S, Gallo A, Srivastava RS. Misra RK. On the Suitability of Nanocrystalline Ferrites as a Magnetic Carrier for Drug Delivery: Functionalization, Conjugation and Drug Release Kinetics. Acta Biomaterialia 2007;3:233-242.

[36] Sun C, Lee JH, Zhang M. Magnetic Nanoparticles in MR Imaging and Drug Delivery. Advanced Drug Delivery Reviews 2008;60:1252-1265.

[37] Chertok B, Moffat BA, David AE, Yu F, Bergemann C, Ross BD, Yang VC. Iron Oxide Nanoparticles as a Drug Delivery Vehicle for MRI Monitored Magnetic Targeting of Brain Tumors. Biomaterials 2008;29:487-496.

[38] Ahamed M, Akhtar MJ, Siddiqui MA, Ahmad J, Musarrat J, Al Khedhairy AA, AlSalhi MS, Alrokayan SA. Oxidative Stress Mediated Apoptosis Induced by Nickel Ferrite Nanoparticles in Cultured A549 Cells. Toxicology 2011;283:101-108.

[39] Johnston HJ, Hutchison, G, Christensen, FM, Peters, S, Hankin, S, Stone V. A Review of the in Vivo and in Vitro Toxicity of Silver and Gold Particulates: Particle Attributes and Biological Mechanisims Responsible for the Observed Toxicity. Critical Reviews in Toxicology 2010;40(4):328-346.

[40] Carlson C, Hussain SM, Schrand AM, Braydich-Stolle LK, Hess KL, Jones RL, Schlager JJ. Unique Cellular Interaction of Silver Nanoparticles: Size-Dependent Generation of Reactive Oxygen Species. Journal of Physical Chemistry B 2008;112:13608-13619.

[41] Park EJ, Yi J, Kim Y, Choi K, Park K. Silver Nanoparticles Induce Cytotoxicity by a Torjan-Horse Type Mechanism. Toxicology in Vitro 2010;24:872-878.

[42] Park EJ, Bae E, Yi J, Kim Y, Choi K, Lee SH, Yoon J, Lee BC, Park K. Repeated-Dose Toxicity and Inflammatory Responses in Mice by Oral Administration of Silver Nanoparticles. Environmental Toxicology and Pharmacology 2010;30:162-168.

[43] Warheit DB, Webb TR, Sayes CM, Colvin VL, Reed KL. Pulmonary Instillation Studies with Nanoscale TiO2 Rods and Dots in Rats: Toxicity is Not Dependent Upon Particle Size and Surface Area. Toxicological Sciences 2006;91:227-236. 
[44] Warheit DB, Webb TR, Reed KL, Frerichs S, Sayes CM. Pulmonary Toxicity Study in Rats with Three Forms of Ultrafine-TiO2 Particles: Differential Responses Related to Surface Properties. Toxicology 2007;230:90-104.

[45] Chen HW, Su SF, Chien CT, Lin WH, Yu SL, Chou CC, Chen JJW, Yang PC. Titanium Dioxide Nanoparticles Induce Emphysema-Like Lung Injury in Mice. The Journal of the Federation of American Societies for Experimental Biology 2006;20:1732-1741.

[46] Jacobsen NR, Moller P, Jensen KA, Vogel U, Ladefoged O, Loft S, Wallin H. Lung Inflammation and Genotoxicity Following Pulmonary Exposure to Nanoparticles in ApoE-/- Mice. Particle and Fibre Toxicology 2009;6(2):1-17.

[47] Gosens I, Post JA, Fonteyne LJJ, Jansen EHJM, Geus JW, Cassee FR, Jong WH. Impact of Agglomeration State of Nano and Submicron Sized Gold Particles on Pulmonary Inflammation. Particle and Fibre Toxicology 2010;7(37):1-11.

[48] Cho WS, Cho M, Jeong J, Choi M, Cho HY, Han BS, Kim SH, Kim HO, Lim YT, Chung $\mathrm{BH}$, Jeong J. Acute Toxicity and Pharmacokinetics of $13 \mathrm{~nm}$-Sized PEG-Coated Gold Nanoparticles. Toxicology and Applied Pharmacology 2009;236:16-24.

[49] Downs TR, Crosby ME, Hu T, Kumar S, Sullivan A, Sarlo K, Reeder B, Lynch M, Wagner M, Mills T, Pfuhler S. Silica Nanoparticles Administered at the Maximum Tolerated Dose Induce Genotoxic Effects through an Inflammatory Reaction wile Gold Nanoparticles Do Not. Mutation Researh 2012;745:38-50.

[50] Song MF, Li YS, Kasai H, Kawai K. Metal Nanoparticle-Induced Micronuclei and Oxidative DNA Damage in Mice. Journal of Clinical Biochemistry and Nutrition 2012;50(3):211-216.

[51] Mroz RM, Schins RP, Li H, Jimenez LA, Drost EM, Holownia A, MacNee W, Donaldson K. Nanoparticle-driven DNA Damage Mimics Irradiation-related Carcinogenesis Pathways. European Respiratory Journal 2008;31:241-51.

[52] Li Y, Chen DH, Yan J, Chen Y, Mittelstaedt RA, Zhang Y, Biris AS, Heflich RH, Chen T. Genotoxicity of Silver Nanoparticles Evaluated Using the Ames Test and in Vitro Micronucleus Assay. Mutation Research 2012;745:4-10.

[53] Ahamed M, Karns M, Goodson M, Rowe J, Hussain SM, Schlager JJ, Hong Y. DNA Damage Response to Different Surface Chemistry of Silver Nanoparticles in Mammalian Cells. Toxicology and Applied Pharmacology 2008;233:404-410.

[54] Kim JS, Sung JH, Ji JH, Song KS, Lee JH, Kang CS, Yu IJ. In Vivo Genotoxicity of Silver Nanoparticles after 90-Day Silver Nanoparticles Inhalation Exposure. Safety and Health at Work 2011;2:34-38.

[55] Kim YS, Kim JS, Cho HS, Rha DS, Kim JM, Park JD, Choi BS, Lim R, Chang HK, Chang YH, Kwon IH, Jeong J, Han BS, Yu IJ. Twenty-Eight-Day Oral Toxicity, Genotoxicity and Gender-Related Tissue Distribution of Silver Nanoparticles in Sprague-Dawley Rats. Inhalation Toxicology 2008;20:575-583.

[56] Falck GC, Lindberg HK, Suhonen S, Vippola M, Vanhala E, Catalan J, Savolainen K, Norppa H. Genotoxic Effects of Nanosized and Fine $\mathrm{TiO}_{2}$. Human \& Experimental Toxicology 2009;28:339-352. 
[57] Rahman Q, Lohani M, Dopp E, Pemsel H, Jonas L, Weiss DG, Schiffmann D. Evidence that Ultrafine Titanium Dioxide Induces Micronuclei and Apoptosis in Syrian Hamster Embryo Fibroblasts. Environmental Health Perspectives 2002;110:797-800

[58] Türkez H, Geyikoglu F. An in Vitro Blood Culture for Evaluating the Genotoxicity of Titanium Dioxide: the Responses of Antioxidant Enzymes. Toxicology and Industrial Health 2007;23:19-23.

[59] Kang SJ, Kim BM, Lee YJ, Chung HW. Titanium Dioxide Nanoparticles Trigger p53Mediated Damage Response in Peripheral Blood Lymphocytes. Environmental and Molecular Mutagenesis 2008;49:399-405.

[60] Wang JJ, Sanderson BJ, Wang H. Cyto- and Genotoxicity of Ultrafine $\mathrm{TiO}_{2}$ Particles in Cultured Human Lymphoblastoid Cells. Mutation Research 2007;28:99-106.

[61] Toyooka T, Amano T, Ibuki Y. Titanium Dioxide Particles Phosphorylate Histone H2AX Independent of ROS Production. Mutation Research 2012;742:84-91.

[62] Hackenberg S, Friehs G, Froelich K, Ginzkey C, Koehler C, Scherzed A, Burghartz M, Hagen R, Kleinsasser N. Intracellular Distribution, Geno- and Cytotoxic Effects of Nanosized Titanium Dioxide Particles in the Anatase Crystal Phase on Human Nasal Mucosa Cells. Toxicology Letters 2010;195:9-14.

[63] Hackenberg S, Friehs G, Kessler M, Froelich K, Ginzkey C, Koehler C, Scherzed A, Burghartz M, Kleinsasser N. Nanosized Titanium Dioxide Particles Do Not Induce DNA Damage in Human Peripheral Blood Lymphocytes. Environmental and Molecular Mutagenesis 2010,52:264-268.

[64] Landsiedel R, Ma-Hock L, Van Ravenzwaay B, Schulz M, Wiench K, Champ S, Schulte S, Wohlleben W, Oesch F. Gene Toxicity Studies on Titanium Dioxide and Zinc Oxide Nanomaterials Used for UV-Protection in Cosmetic Formulations. Nanotoxicology 2010;4:364-381.

[65] Kocbek P, Teskac K, Kreft ME, Kristl J. Toxicological Aspects of Long-Term Treatment of Keratinocytes with ZnO and TiO2 Nanoparticles. Small 2010,6:1908-1917.

[66] Warheit DB, Hoke RA, Finlay C, Donner EM, Reed KL, Sayes CM. Development of a Base Set of Toxicity Tests Using Ultrafine TiO2 Particles as a Component of Nanoparticle Risk Management. Toxicology Letters 2007;171:99-110.

[67] Theogaraj E, Riley S, Hughes L, Maier M, Kirkland D. An Investigation of the PhotoClastogenic Potential of Ultrafine Titanium Dioxide Particles. Mutation Research 2007;634:205-219.

[68] Naya M, Kobayashi N, Ema M, Kasamoto S, Fukumuro M, Takami S, Nakajima M, Hayashi M, Nakanishi J. In Vivo Genotoxicity Study of Titanium Dioxide Nanoparticles Using Comet Assay Following Intratracheal Instillation in Rats. Regulatory Toxicology and Pharmacology 2012;62:1-6.

[69] Schulz M, Hock LM, Brill S, Strauss V, Treumann S, Groters S, Ravenzwaay BV, Landsiedel R. Investigation on the Genotoxicity of Different Sizes of Gold Nanoparticles Administered to the Lungs of Rats. Mutation Research 2012;745:51-57.

[70] Sharma V, Singh SK, Anderson D, Tobin DJ, Dhawan A. Zinc Oxide Nanoparticle Induced Genotoxicity in Primary Human Epidermal Keratinocytes. Journal of Nanoscience and Nanotechnology 2011;11(5):3782-3788. 
[71] Sharma V, Anderson D, Dhawan A. Zinc Oxide Nanoparticles Induce Oxidative Stress and Genotoxicity in Human Liver Cells (HepG2). Journal of Biomedical Nanotechnology 2011;7(1):98-99.

[72] Oberdorster G. Safety Assessment for Nanotechnology and Nanomedicine: Concepts of Nanotoxicology. Journal of Internal Medicine 2010;267:89-105.

[73] Oberdorster G, Maynard A, Donaldson K, Castranova V, Fitzpatrick J, Ausman K, Carter J, Karn B, Kreyling W, Lai1 D, Olin S, Monteiro-Riviere N, Warheit D, Yang and A Report From the ILSI Research Foundation / Risk Science Institute Nanomaterial Toxicity Screening Working Group. Principles for characterizing the potential human health effects from exposure to nanomaterials: elements of a screening strategy. Particle and Fibre Toxicology 2005;2:8.

[74] Oberdorster G: Pulmonary Effects of Inhaled Uultrafine Particles. International Archives of Occupational and Environmental Health 2001;74:1-8.

[75] Sayes CM, Reed KL, Warheit DB. Assessing Toxicity of Fine and Nanoparticles: Comparing In Vitro Measurements to In Vivo Pulmonary Toxicity Profiles. Toxicological Sciences 2007; 97:163-80.

[76] Rushton EK, Jiang J, Leonard SS et al. Concept of assessing nanoparticle hazards considering nanoparticle dosemetric and chemical / biological response-mixes. Journal of Toxicology and Environmental Health, Part A 2010;73:445-461. 